\section{A baseline taxonomic study of zooplankton in the lower Halda River, Bangladesh}

\author{
Istiak Ahamed Mojumder ${ }^{1}$, Md. Manzoorul Kibria ${ }^{1}$ and \\ Md. Simul Bhuyan ${ }^{2 *}$ \\ ${ }^{1}$ Halda River Research laboratory, Department of Zoology, University of Chittagong, Chittagong, \\ Bangladesh \\ ${ }^{2}$ Faculty of Marine Sciences and Fisheries, University of Chittagong, Chittagong, Bangladesh
}

Received: 09 October, 2019

Accepted: 09 January, 2020

Published: 10 January, 2020

*Corresponding author: Md. Simul Bhuyan, Faculty of Marine Sciences and Fisheries, University of Chittagong, Chittagong, Bangladesh, Tel: +8801849752555; E-mail: simulbhuyan@gmail.com

Keywords: Taxonomy; Composition; Zooplankton; Indian major carps; Lower Halda River

https://www.peertechz.com

\section{Check for updates}

\begin{abstract}
Halda is a unique resourceful tidal river of Bangladesh, where Indian major carps (Catla catla, Labeo rohita, Cirhinnus mrigala, and Labeo calbasu) spawn from April to June. Ecological conditions are auspicious from time immemorial which serves as a natural breeding ground in the world. The present study was conducted over the period of January-June 2017 to identify the main species of Zooplankton fauna and also find out the dominancy of the highest plankton groups in the lower Halda River. A total of 3 major zooplankton groups-Copepoda, Rotifera and Cladocera were identified during the six months period. A total of 35 species under 4 family showing the dominancy for the class Rotifera consisting of 7 genera were recorded from five sampling sites. The lowest group was Cladocera consisting of 5 genera. The composition and dominance of the zooplankton community among five different sites in the lower Halda River showed some close inter-relationships. The present study suggests for conducting further research to know the overall conditions and to make a complete list of available zooplankton fauna that exert impact on the water quality of the Halda River.
\end{abstract}

\section{Introduction}

Bangladesh is blessed with small and large rivers which are mostly covered with water. The Halda River is one of the most unique resourceful rivers of Bangladesh where Indian major carps (Catla catla, Labeo rohita, Cirrhinus mrigala, and Labeo calbasu) spawn during April to June [1-3]. The river also provides navigations, supplies drinking water and generate employment opportunities for the local communities [1].

The biotic community of an ecosystem gives an insight into the conditions existing in the aquatic ecosystem. Changes in the structure and function of biological systems are induced by environmental disturbances in the composition of aquatic communities of rivers [4]. Zooplankton is one of the four selected bioindicators (benthic diatom, zooplankton, littoral macroinvertebrate, and benthic macroinvertebrate), uses for assessment in Ecological Health Monitoring (EHM) [5]. Zooplankton is considered the most important link between planktonic primary producers and large carnivores, amongst them fish species subject to human exploitation. They are minute aquatic animals that are non-motile or very weak swimmers. They serve as a good indicator of changes in water quality because it is strongly affected by the environment quality [6]. They play a crucial role in indicating the presence or absence of certain fishes. Zooplankton population is able to reflect the nature and potential of any aquatic systems $[7,8]$.

Zooplankton constitutes an important food item of many omnivorous and carnivorous fishes. The larvae of white fish (Mullet) feed mostly on zooplankton [9], because zooplankton provides the necessary amount of protein for the rapid growth and especially that of the gonad. Zooplankton contributes about $82 \%$ of the food item of Anabas testudineus [10], $32 \%$ of Notopterus notopterus [11]. The main food item of Xenentodon cancila and the zooplankton contributes about $23 \%$ of the food item of Macrobrachium rosenbergii, $47 \%$ of the Catla catla and $6.37 \%$ of the Labeo rohita [12].

Resources of the Halda River are depleting day by day due to over-fishing, straightening of existing ox-bow bands, sedimentation on the river bed, changes in water quality, 
mismanaged sluice gate establishment, mechanical sand quarrying, water contamination with industrial wastes, denudation of various species of fishes towards gradual extinction including carps, unchecked riverbank erosion and above all global climate change [1]. Time may come when no more seed will be available from the Halda if the Halda River ecosystem destroyed. Therefore, the protection of the Halda River is an urgent need because most of the country's pond carp culture reliant on the fish fry naturally produced in this river which is of insurmountable economic and nutritional value.

The taxonomic checklist of zooplankton along with its occurrence and distribution in the lower Halda River has become a prerequisite for fish production. Available information about the Halda River reveals that only a few works have so far been done in the country by different researchers. Thus, there is a research gap that needs to be bridged. Considering these facts, the present study was aimed to determine the main species of zooplankton fauna in the lower Halda River, Chittagong by making its list in terms of zooplankton species composition and group's dominance. The present study will be a preliminary baseline for the zooplankton study in the lower Halda River.

\section{Materials and methods}

\section{Study Area}

The present study was carried out in the tidal Halda River $\left(22^{\circ} 54^{\prime} \mathrm{N}\right.$ and $91^{\circ} 48^{\prime} \mathrm{E}$ to $22^{\circ} 24^{\prime} \mathrm{N}$ and $91^{\circ} 53^{\prime} \mathrm{E}$ ), one of the tributaries of the River Karnaphuli originated from Haldachora at the area of 2 no (Table 1, Figure 1). Patachora Union in Ramgarh Upazila under Khagrachari districts (former Chittagong Hill Tracts), Bangladesh [13]. A number of canals such as Manikchori Khal, Khondokia Khal, Madari Khal, Khata Khal are connected with the Halda River and make Halda Khal a river $[13,14]$.

\section{Geological information}

Five important sites named Karnaphuli (estuary), Krisno Khal, Khandokia Khal, Madari Khal and Garduara (Noyahat) were selected purposively for sample collection. There are a number of canals in the fish sanctuary of the Halda River. Khandokia Khal is one of the most polluted canals where untreated wastewater from the adjacent industries and Anannya residential area flow through the canal and finally ends up in the Halda River. Kalurghat is the confluence point of Halda and Karnaphuli River. Saline water from the Bay of Bengal enters the Halda River through the Karnaphuli River. During ebb and flow, the water of the Karnaphuli River mixes with the water of the Halda River through this confluence point. These indirectly

Table 1: Geographical positions of the sampling sites.

\begin{tabular}{|c|c|c|c|}
\hline \multirow{2}{*}{ Stations No. } & \multirow{2}{*}{ Name of the sites } & \multicolumn{2}{|c|}{ GPS locations } \\
\hline & & Latitude & Longitude \\
\hline Site $1\left(\mathrm{~S}_{1}\right)$ & Karnaphuli (estuary) & N 22²3'59" & E $91^{\circ} 53^{\prime} 17^{\prime \prime}$ \\
\hline Site $2\left(\mathrm{~S}_{2}\right)$ & Krisno Khal & N $22^{\circ} 30^{\prime} 10^{\prime \prime}$ & E $91^{\circ} 52^{\prime} 7^{\prime \prime}$ \\
\hline Site $3\left(\mathrm{~S}_{3}\right)$ & Khondokia Khal & $\mathrm{N} 22^{\circ} 43^{\prime} 05^{\prime \prime}$ & E $91^{\circ} 87^{\prime} 54^{\prime \prime}$ \\
\hline Site $4\left(S_{4}\right)$ & Madari Khal & N $22^{\circ} 26^{\prime} 58^{\prime \prime}$ & E $91^{\circ} 51^{\prime} 32^{\prime \prime}$ \\
\hline Site $5\left(S_{5}\right)$ & Garduara (Noyahat) & N $22^{\circ} 50^{\prime} 01^{\prime \prime}$ & E $91^{\circ} 86^{\prime} 59^{\prime \prime}$ \\
\hline
\end{tabular}

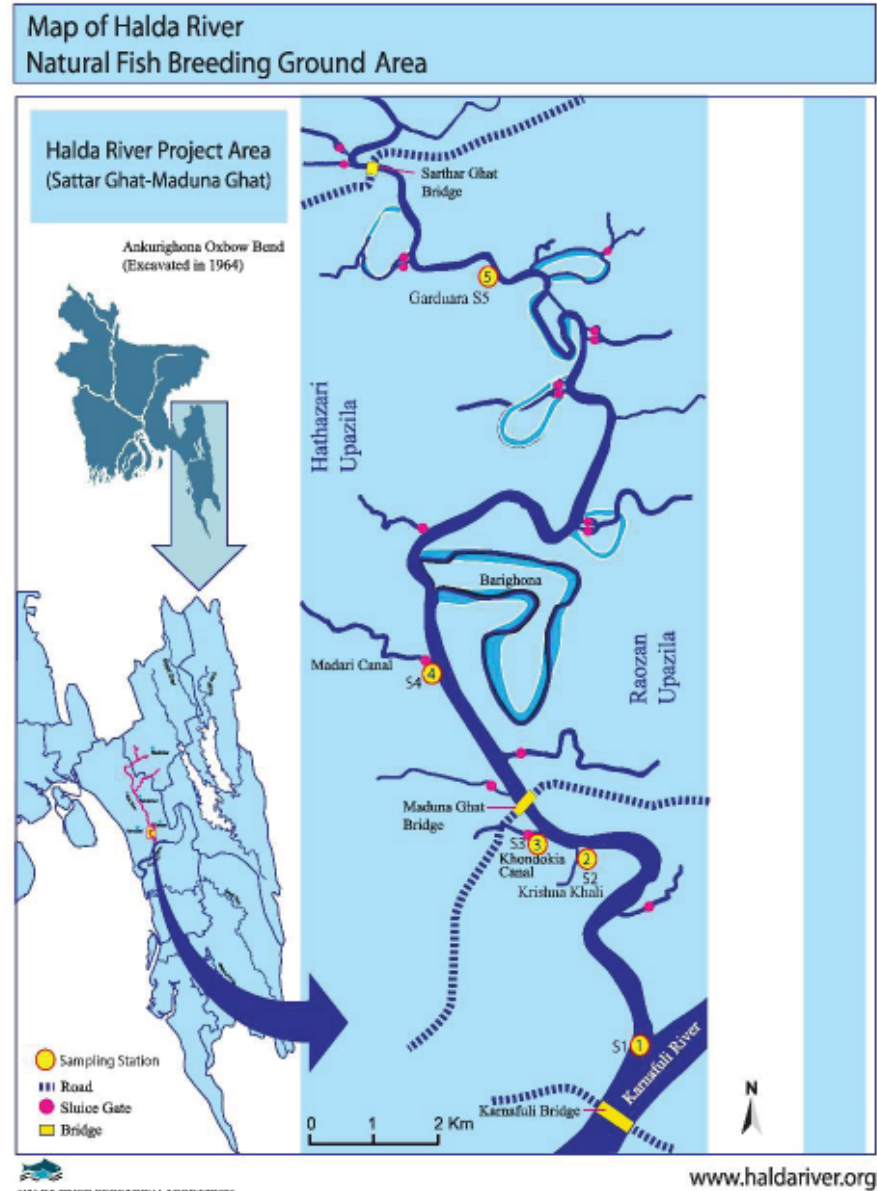

Figure 1: Map showing the sampling sites of the study area.

bring the pollutants in the Halda River. The study of plankton of these sites gives an insight into the effects of environmental variables on the biodiversity and ecosystem of the Halda River and how the overall productivity fluctuates from site to site as well as gives the decision-makers a basis for coming up with its better management.

\section{Sampling duration}

The sampling was carried out from January to June 2018. Water samples containing zooplankton were collected from selected five points over the period of six months at the time of 6:30-10:00am but some time due to unfavorable condition time had to change. Samples were collected every month form every site.

\section{Sample collection and preservation}

Zooplankton samples were collected from the subsurface water using a zooplankton net of $70 \mu \mathrm{m}$ mesh size. A flow meter was attached at the mouth of the net. The net was thrown to the desired distance $(7 \mathrm{~m})$ and allowed to reach the desired depth of the sampling sites from the boat. Then the throne rope with the net was pulled quickly towards the boat for the collection of samples. The water was passed down through the net and the plankton condensed at the end of the plankton net then it was collected into a glass test tube and fixed firmly. The 
net was pulled 3 times from several places of the sites. Then the samples were transferred to a plastic jar, labeled detective of time, date and sampling sites. The collected samples were preserved in $5 \%$ formalin in the plastic jars immediately after collection and were taken to the laboratory of the Department of Zoology, University of Chittagong. For further study, samples were preserved in $70 \%$ alcohol.

\section{Identification}

The sorted organisms were brought under microscope and identified following Ahlstrom [15], Edmondsom [16], Davis [17], Pennak [18], Needham and Needham [19], Williamson [20], Brooks [21], Wilson [22], Wilson and Yeatman [23], Smith and Fernando [24], Battish [25], Bhouiyan and Asmat [26], Macan [27], Das and Bhouiyan (1974), Mellanby [28], Delorme [29], Wickstead [30], Mizuno [31], Nayar and Nair [32], Ward and Whipple (1963), Balcer, et al., [33], Victor and Fornando [34], Ahmed [35]; Elias [36]; Zafar [37]; Mohi [38] etc.

\section{Results and discussion}

\section{Zooplankton species composition}

A total of 35 species of zooplankton was identified. 15 species of Rotifera belonging to 4 family and 7 genera; 9 species of Copepoda belonging to 2 family and 5 genera; 9 species of Cladocera belonging to 4 family and 5 genera also pelecypod larva, Nauplius larva, etc. were recorded from the lower Halda River during the study period. Major taxa of zooplankton which was found during the investigation were presented in Table 2.

The dominance of Rotifera was due to its preference for warm waters as highlighted by Dumont [39]. The dominance of Brachionus is an indication that the Halda River is eutrophic and their abundance due to the presence of high levels of organic matter in the river basically at Khondokia Khal (Figure 2). The relatively low species diversity of Copepoda and Cladocera was a result of the hydrodynamics of the river such as low water volume, short residence time and morphometric.

Table 2: Major taxa of zooplankton along with their characteristics.

\begin{tabular}{|c|c|c|c|c|}
\hline SL. no. & Taxonomy & Key Identifying Characters & The Halda River Distribution & Image of Identified Species \\
\hline 1. & $\begin{array}{l}\text { Phylum : Rotifera } \\
\text { Class : Bdelloidea } \\
\text { Order : Bdelloida } \\
\text { Family : Philodinidae } \\
\text { Genus : Philodina } \\
\text { Species : Philodina roseola }\end{array}$ & $\begin{array}{l}\text { 1. Head distinct from the trunk. } \\
\text { 2. The surface of the trunk is smooth. } \\
\text { Two distinguished toe present. }\end{array}$ & Gorduara (Noyahat) & Philodina roseola \\
\hline 2. & $\begin{array}{l}\text { Phylum : Rotifera } \\
\text { Class : Monogononta } \\
\text { Order : Ploima } \\
\text { Family : Brachionidae } \\
\text { Genus : Brachionus } \\
\text { Species : Brachionus caudatus }\end{array}$ & $\begin{array}{l}\text { 1. Lorica ovate, transparent, medial slightly wide. } \\
\text { 2. Lorica surface ornamentation, with four occipital } \\
\text { spines. } \\
\text { 3. Two divergent posterior spines }\end{array}$ & $\begin{array}{l}\text { Gorduara (Noyahat), Krisno Khal, } \\
\text { Garduara (Noyahat) }\end{array}$ & Brachionus caudatus \\
\hline 3. & $\begin{array}{l}\text { Phylum : Rotifera } \\
\text { Class : Monogononta } \\
\text { Order : Ploima } \\
\text { Family : Brachionidae } \\
\text { Genus : Brachionus } \\
\text { Species : Brachionus } \\
\text { calyciflorus }\end{array}$ & $\begin{array}{l}\text { 1. Lorica oval, flexible \& smooth. } \\
\text { 2. Anterior dorsal margin with } \\
\text { four broad-based spines. } \\
\text { 3. Lateral posterior with a pair of large spines or } \\
\text { absent. }\end{array}$ & $\begin{array}{l}\text { Gorduara (Noyahat), } \\
\text { Madari Khal }\end{array}$ & Brachionus calyciflorus \\
\hline 4. & $\begin{array}{l}\text { Phylum : Rotifera } \\
\text { Class : Monogononta } \\
\text { Order : Ploima } \\
\text { Family : Brachionidae } \\
\text { Genus : Brachionus } \\
\text { Species: Brachionus } \\
\text { diversicornis }\end{array}$ & $\begin{array}{l}\text { 1. Lorica tumbler-shaped, firm, elongate } \& \text { half of } \\
\text { anterior wider than posterior. } \\
\text { 2. Posterior lorica with two unequal spines. } \\
\text { 3. Right posterior spine longer than the left spine. }\end{array}$ & Karnaphuli (Estuary) & Brachionus diversicornis \\
\hline 5. & $\begin{array}{l}\text { Phylum : Rotifera } \\
\text { Class : Monogononta } \\
\text { Order : Ploima } \\
\text { Family : Brachionidae } \\
\text { Genus : Brachionus } \\
\text { Species : Brachionus forficula }\end{array}$ & $\begin{array}{l}\text { 1. Anterior dorsal margin with four occipital spines. } \\
\text { 2. Lateral spines slightly longer than median spines. } \\
\text { 3. Posterior of lorica with a pair of spines stout, long, } \\
\text { subequal, curved inward. }\end{array}$ & Madari Khal & $\underbrace{}_{\text {Brachionus forficula }}$ \\
\hline 6. & $\begin{array}{l}\text { Phylum : Rotifera } \\
\text { Class : Monogononta } \\
\text { Order : Ploima } \\
\text { Family : Brachionidae } \\
\text { Genus : Brachionus } \\
\text { Species : Brachionus falcatus }\end{array}$ & $\begin{array}{l}\text { 1. Anterior dorsal margin with six unequal spines. } \\
\text { 2. Lateral and median spines short subequal. } \\
\text { 3. Posterior lorica margin with two spines very long, } \\
\text { slightly curved inward. }\end{array}$ & $\begin{array}{l}\text { Krisno Khal, Khondokia Khal, } \\
\text { Madari Khal }\end{array}$ & Brachionus falcatus \\
\hline
\end{tabular}


Phylum : Rotifera

Class : Monogononta

Order : Ploima

Family : Brachionidae

Genus : Brachionus

Species : Brachionus rubens

Class : Monogononta

Order : Ploima

Family : Brachionidae

Genus : Platyias

Species : Platyias quadricornis

Phylum : Rotifera

Class : Monogononta

Order : Ploima

Family : Brachionidae

Genus : Keratella

Species : Keratella tropica

10. Phylum : Rotifera

Class : Monogononta

Order : Ploima

Family : Brachionidae

Genus : Keratella

Species : Keratella cochlearis

11. Phylum : Rotifera

Class : Monogononta

Order : Ploima

Family : Brachionidae

Genus : Keratella

Species : Keratella valga

12. Phylum : Rotifera

Class : Monogononta

Order : Ploima

Family : Lecanidae

Genus : Lecane

Species : Lecane ungulata

13. Phylum : Rotifera

Class : Monogononta

Order : Ploima

Family : Testudinellidae

Genus : Testudinella

Species : Testudinella patina

14. Phylum : Rotifera

Class : Monogononta

Order : Ploima

Family : Testudinellidae

Genus : Filinia

Species : Filinia opoliensis

15. Phylum : Rotifera

Class : Monogononta

Order : Ploima

Family : Testudinellidae

Genus : Filinia

Species : Filinia camasecla

16. Phylum : Arthropoda

Order : Cladocera

Family : Bosminidae

Genus : Bosmina

Species : Bosmina longirostris

17
Class : Branchiopoda

1. Anterior dorsal margin with large spines.

2. Median spines longest, stout, curved inward.

3. Posterior lorica with two spines, unequal, right spine always longer than left.

1. Anterior dorsal margin with six spines.

2. Median spines longer than others and curved

outward.

3. Posterior lorica margin with a long, stout spine

1. The width of the body proper is greater at the anterior end than at the posterior end.

2. The Anterior spines are unequal in length.

3. Posterior spines developed.

1. Lorica large, broadly oval

2. Anterior dorsal margin nearly straight

3. Toes straight.

1. Lorica margin almost circular, thin, transparent.

2. Anterior dorsal margin rounded.

3. Toes reduced by a circling of ciliate

1. Lorica cylindrical elongate.

2. Anterior with two long spines with broad-bases, unequal underneath the corona.

3. Posterior lorica with two spines unequal.

\section{Lorica heart-shaped.}

2. Lateral of lorica with two spines.

3. Posterior lorica margin with a pointed, straight spine.
1. The postabdominal claw is slightly curved.
2. The posterodorsal corner nearly perpendicular.
3. Antennules long.

Phylum : Arthropoda
Class : Branchiopoda
Order : Cladocera
Family : Bosminidae
Genus : Bosmina
Species: Bosmina longispina
1. Rostrum usually short and blunt.
2. Antennules are weakly curved.
3. The frontal part of the head humped.

1. Antero-dorsal lorica margin with six spiricans.
2. Median spines somewhat longer than other spines.
3. Posterior spines absent.

1. Lorica surface with small tuberculate, slight compressed dorsal-ventral.

2. Anterior dorsal margin with two spines.

3. Posterior lorica margin with a pair spines
Garduara (Noyahat)

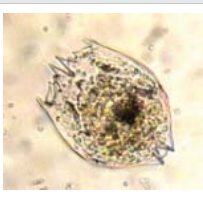

Brachionus rubens

Khondokia Khal

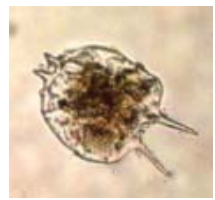

Platyias quadricornis

Krisno Khal, Khondokia Khal

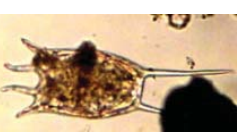

Keratella tropica

Khondokia Khal

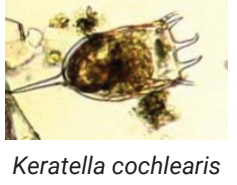

Garduara (Noyahat),

Madari Khal

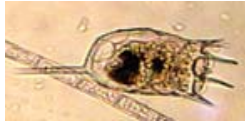

Keratella valga

Khondokia Khal, Garduara

(Noyahat)

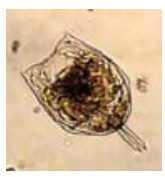

Lecane ungulata

Garduara (Noyahat)

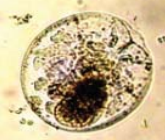

Testudinella patina

Madari Khal

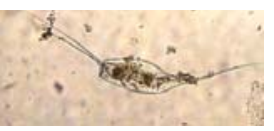

Filinia opoliensis

Khondokia Khal, Garduara

(Noyahat)

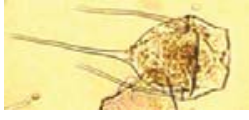

Filinia camasecla

Khondokia Khal, Madari Khal,

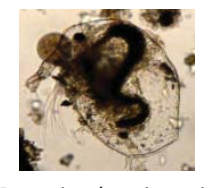

Bosmina longirostris

Khondokia Khal

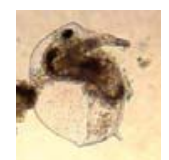

Bosmina longispina

Citation: Mojumder IA, Kibria MM, Bhuyan MS (2020) A baseline taxonomic study of zooplankton in the lower Halda River, Bangladesh. Glob J Zool 5(1): 001-008. DOI: https://dx.doi.org/10.17352/gjz.000013 
Phylum : Arthropoda Class : Branchiopoda Order : Cladocera

Family : Sididae

Genus : Diaphanosoma

Species : Diaphanosoma

brachyurum

19. Phylum : Arthropoda

Class : Branchiopoda

Order : Cladocera

Family : Sididae

Genus : Diaphanosoma

Species : Diaphanosoma

leuchtenbergianum

20. Phylum : Arthropoda

Class : Branchiopoda

Order : Cladocera

Family : Moinidae

Genus : Moina

Species : Moina macrocopa

21. Phylum : Arthropoda

Class : Branchiopoda

Order : Cladocera

Family : Moinidae

Genus : Moina

Species : Moina brachiata

22. Phylum : Arthropoda

Class : Branchiopoda

Order : Cladocera

Family : Moinidae

Genus : Moina

Species : Moina micrura

23. Phylum : Arthropoda

Class : Branchiopoda

Order : Cladocera

Family : Daphniidae

Genus : Daphnia

Species : Daphnia lumholtizi

24. Phylum : Arthropoda

Class : Branchiopoda

Order : Cladocera

Family : Daphniidae

Genus : Ceriodaphnia

Species : Ceriodaphnia cornuta

25. Phylum : Arthropoda

Class : Copepoda

Order : Calanoida

Family : Diaptomidae

Genus : Skistodiaptomus

Species : Skistodiaptomus

pallidus

26. Phylum : Arthropoda

Class : Copepoda

Order : Cyclopoida

Family : Cyclopidae

Genus : Cyclops

Species : Cyclops varicans

rubellus

27. Phylum : Arthropoda

Class : Copepoda

Order : Cyclopoida

Family : Cyclopidae

Genus : Cyclops

Species : Cyclops nanus

28. Phylum : Arthropoda

Class : Copepoda

Order : Cyclopoida

Family : Cyclopidae

Genus : Microcyclops

Species : Microcyclops varicans
1. Body long transparent open valve.

2. Eye pigment black, filling the end of the head

3. Post abdominal claw with the basal spines.

1. Body flattened, covered by the transparent valve.

2. The reflexed antennae exceeded posterior margin

of the valves.

3. Head broad, eye lanceolate.

1. Head extended, broad and round.

2. Eye larger, situated in the middle of the head

3. Antennae also larger and covered with thick setules.

1. Body stout with the large and broad carapace.

2. Head large and depressed without rostrum and ocellus.

3. Antennules are large with olfactory setae.

1. Anntenules are large.

2. Head with supraocular depression

3. Eye larger, situated on the top of the head.

1. Long helmet and tail spine.

2. The tail spine is normally at least as long as the body length.

3. Fornices sharp \& pointed.

1. Head small and depressed

2. Antennules short and broad

3. Claw shorter.

1. The antennules reach beyond the furcal setae.

2. The modified right geniculate antennule bears spines.

3. The end claws are slightly curved.

1. The body rounded at the anterior tip and gradually decreases in size at posterior end

2. Articulation between metasoma and urosome is distinct.

3. Lateral caudal seta present.

1. The body is slender with a distinct articulation between metasome and urosome.

2. Innermost terminal caudal setae are shorter than outer.

3. Lateral caudal seta at about the middle of ramous.

1. The body is small.

2. The outer seta longer than the inner seta.

3. The lateral seta is attached close to the end of a relatively short furca.
Khondokia Khal

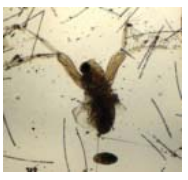

Diaphanosoma brachyurum

Garduara (Noyahat), Madari Khal

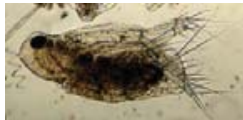

Diaphanosoma leuchtenbergianum

Garduara (Noyahat)

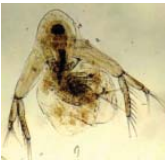

Moina macrocopa

Madari Khal, Garduara (Noyahat)

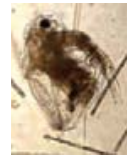

Moina brachiata

Garduara (Noyahat)

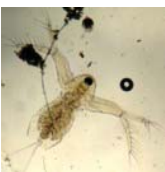

Moina micrura

Khondokia Khal, Madari Khal

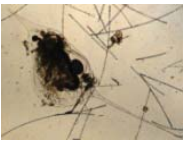

Daphnia lumholtizi

Garduara (Noyahat)

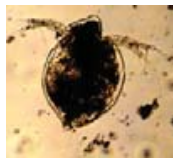

Ceriodaphnia cornuta

Garduara (Noyahat)

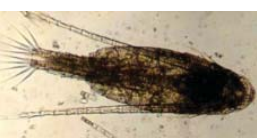

Skistodiaptomus pallidus

Khondokia Khal, Garduara

(Noyahat), Madari Khal

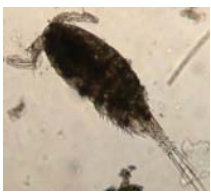

Cyclops varicans rubellus

Madari Khal

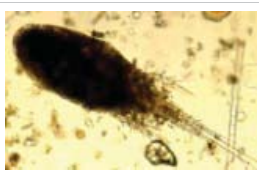

Cyclops nanus

Khondokia Khal, Krisno Khal,

Garduara (Noyahat)

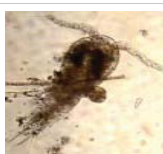

Microcyclops varicans

Citation: Mojumder IA, Kibria MM, Bhuyan MS (2020) A baseline taxonomic study of zooplankton in the lower Halda River, Bangladesh. Glob J Zool 5(1): 001-008. DOI: https://dx.doi.org/10.17352/gjz.000013 
Phylum : Arthropod

Class : Copepoda

Order : Cyclopoida

Family : Cyclopidae

Genus : Microcyclops

Species : Microcyclops

rubellus

30. Phylum : Arthropoda

Class : Copepoda

Order : Cyclopoida

Family : Cyclopidae

Genus : Mesocyclops

Species : Mesocyclops

leuckarti

31. Phylum : Arthropoda

Class : Copepoda

Order : Cyclopoida

Family : Cyclopidae

Genus : Mesocyclops

Species : Mesocyclops edax

32. Phylum : Arthropoda

Class : Copepoda

Order : Cyclopoida

Family : Cyclopidae

Genus : Thermocyclops

Species : Thermocyclops

crassus

Phylum : Arthropoda

Class : Copepoda

Order : Cyclopoida

Family : Cyclopidae

Genus : Thermocyclops

Species : Thermocyclops

oithonoides
1. The body is robust with a distinct articulation between metasoma and urosome.
2. Metasome 4 segmented.
3. Antennae are symmetrical.
Garduara (Noyahat)

1. Elliptical-shaped body

2. Sixth foot with a long outer marginal seta.

3. Antennae curved at the terminal.

\author{
1. Spines or setae are long. \\ 2. Long palmately spread terminal setae on the cauda \\ rami. \\ 3. Adult females bear two egg sacs on either side of \\ their urosome.
1. Body slender.
2. First antenna curved at terminal part \\ 3. Furca rami short. \\ 1. Long and slender body form. \\ 2. The short length of the outer seta attached to the \\ furca. \\ 3. Body is highly pellucid, with a faint yellow tinge.
}

Karnaphuli (Estuary), Krisno Khal, Garduara (Noyahat),

Madari Khal

Garduara (Noyahat)
Karnaphuli (Estuary), Krisno Khal,
Garduara (Noyahat),
Madari Khal

Khondokia Khal

Microcyclops rubellus

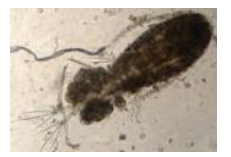

Mesocyclops leuckarti

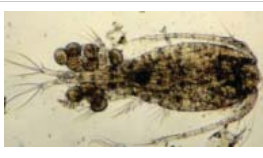

Mesocyclops edax

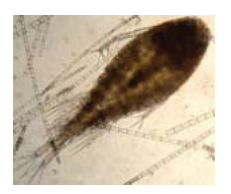

Thermocyclops crassus

Garduara (Noyahat)

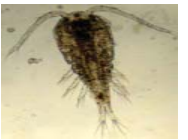

Thermocyclops oithonoides

1. The very young stage of animals that live in shells. 2. Has 2 distinct sides (bivalves) such as oysters, clams and mussels.

3. Looks like a clam and the body inside has cilia that it uses for a graceful, swimming motion.

1. Early stage of a copepod.

2. Has six "legs" and swims quickly with a jumping motion.

3. The various species can have very different looking nauplii.
Garduara (Noyahat)

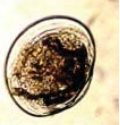

Pelecypod larva

Khondokia Khal,

Garduara (Noyahat), Madari Khal

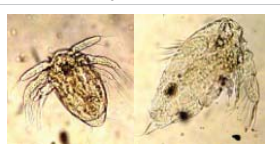

Nauplius stages of copepod

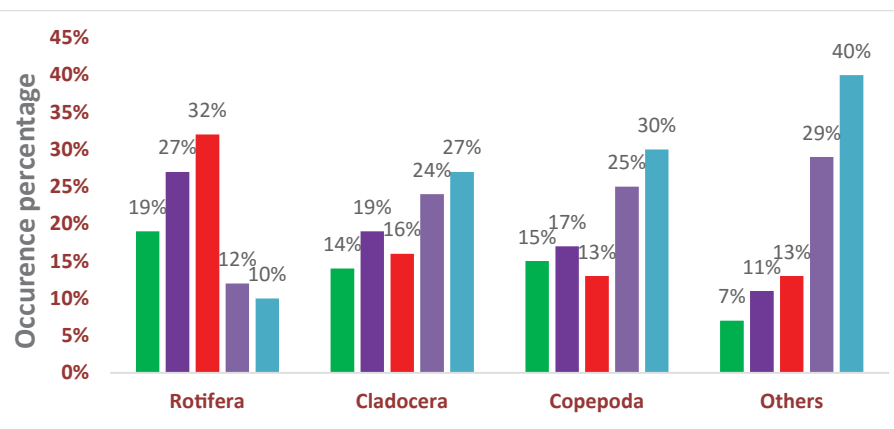

Zooplankton groups

Estuary Krisno Khal Khondokia Khal Madari Khal Garduara(Noyahat)

\section{Figure 2: Percentage of various groups of Zooplankton in five different sites.}

The low genera diversity of Copepoda and Cladocera has also been documented in the other water bodies [40], the Ogun and Ona rivers [41] and the Niger-sokoto River [42]. According to Rocha, et al., [43], an increase a primary production (phytoplankton) tends to be followed by an increase in zooplankton number and biomass. Lampert [44], have emphasized these factors as being responsible for zooplankton number and biomass reduction. Food resource [45], the ability to adapt to food conditions and less predation [46], maybe the reasons for the significant abundance of Rotefers, Cladocera, and Copepoda in the aquatic ecosystem. Generally, the zooplankton community of the Halda River was dominated by Rotifera, which due to their short generation time and their high reproductive rate, dominate in rivers. Among the species identified, rotifer regarded as the indicators of eutrophication in the river, the rotifer Brachionus stands in its great tolerance to extremely eutrophic environments [47], Regarded it as a good indicator of eutrophication.

The abundance of the genera Brachionus and Keratella showed that rotifer fauna was made up of atypical tropical assemblage. The predominance of Brachionidae could, however, be attributed to their omnivorous nutrition and the widespread geographical distribution of most of the members

Citation: Mojumder IA, Kibria MM, Bhuyan MS (2020) A baseline taxonomic study of zooplankton in the lower Halda River, Bangladesh. Glob J Zool 5(1): 001-008. DOI: https://dx.doi.org/10.17352/gjz.000013 
[48]. In the present investigation, members of Brachionidae were dominant both in species numbers.

Members of the rotifer were dominant at Khondokia Khal and Krisno Khal of the Halda River during the investigation period comparatively more than that of the other three sites. Due to industrial and municipal wastes and also other factors the abundance of Brachionus is a common fact at Khondokia Khal and Krisno Khal of the Halda River. Because Brachionus, Keratella, and Lecane sp. are considered as euryhaline and suggested as mesohaline indicators and tolerance high ranges of salinity [49-53].

\section{Conclusion}

The findings of the present study indicate that zooplankton occupies a significant position in the river ecosystem. The Halda River is mostly known for its natural spawning instance. Zooplankton diversity in this river is an important criterion for natural spawning instance. Most of the taxa of zooplankton was highly variable over time. As they constitute the most important link in the energy transfer between phytoplankton and higher aquatic fauna. They are essential for estimation of secondary production and fishery potential of a water body. Almost every fish depends on Zooplankton in their entire life cycle. Since the Zooplankton community is an integral part of tropic level, conservation is very essential for healthy and sustainable ecosystem management. It can be concluded that the occurrence of zooplankton required for maintaining sustainable healthy conditions in the Halda River. The presence of zooplankton communities was higher in Garduara (Noyahat) than the other four sites because it is called the main breeding point of the Halda River where flow of industrial wastewater is very low. On the other hand, the presence of zooplankton communities was very low in Khondokia Khal because different industries are connected to this Khal. As a result, water becomes polluted and ultimately these polluted water are getting mixed with the Halda River through Khondokia Khal. The presence of zooplankton communities is decreasing at an alarming rate due to various types of natural and anthropogenic disturbance, withdraw of water from the upstream, global climate change, etc. Besides, highly fluctuation of various Zooplankton communities reveals a sign of serious threat to destroy the natural ecosystem in the Halda River.

\section{Limitations}

As it was a study of six months period it cant be concluded the overall problems of the Halda River ecosystem. Long timeintensive research will give a better result which will be more effective to conserve the biodiversity of the Halda River.

\section{References}

1. Kabir MH, Kibria MM, Russell LA, Hossain MM (2014) Engineering activities and their mismanagement at Halda: a unique tidal river for natural spawning of Major Indian Carps. Int J Surface Groundwater Manage 1: 59-66. Link: http://bit.ly/37SWPBs

2. Chowdhury SQ (2012) "Halda River" Banglapedia: National Encyclopedia of Bagladesh ( $2^{\text {nd }}$ edition). Asiatic Society of Bangladesh.
3. Akter A, Ali MH (2012) Environmental flow requirements assessment in the Halda River, Bangladesh. Hydrological Sciences Journal 57: 326-343. Link: http://bit.ly/2t2ZWYV

4. Ahmed KKU, Ahamed SU, Hossain MRA, Ahmed T, Barman S (2003) Quantitative and qualitative assessment of plankton: some ecological aspect and water quality parameters of the river Meghna, Bangladesh. Bangladesh Fish Res 7: 131-140. Link: http://bit.ly/2tHi4aS

5. MRCEP (Mekong River Commission Environmental Programme) (2015) Identification Handbook of Freshwater Zooplankton of the Mekong River and its Tributaries. Mekong River Commission Vientiane Laos 197. Link: http://bit.ly/37TMPrP

6. Gannon JE, Stemberger RS (1978) Zooplankton (especially Crustaceans and Rotifers) as indicators of water quality. Trans Am Microsc Soc 97: 16-35. Link: http://bit.ly/2tOm3CA

7. Sharif ASM, Islam MM, Bhuyan MS (2017) Zooplankton in the lower Meghna River and its Estuary with Relation to Physico-Chemical Parameters, Bangladesh. International J Zool Studi 2: 6-15. Link: http://bit.ly/2QFMkvz

8. Kumar NJl, Yamini V, Kumar RN (2011) Spatial analysis of composition and species interactions with temporal variation of zooplankton community of shallow tropical lake: thol Bird Sanctuary, India. Universal journal of Environmental Research and Technology 1: 151-159. Link: http://bit.ly/39VNA5C

9. Dewan S, Ali M, Islam MA (1977) Study on the size and patterns of feeding of fries and fingerlings of three major carps. Viz labeo rohita (Ham), Catla catla (Ham), cirrhina mrigala (Ham). Bangladesh J Agricult 2: 223-228.

10. Shafi M, Mustafa G (1976) Observation on some aspects of biology of climbing perch, Anabas testudineus (Bloch). Bangladesh J Zoolo 4: 21-28. Link: http://bit.ly/36Ffwsp

11. Mustafa G, Ahmed ATA (1979) Food of Notopterus notopterus (Pallas) Bangladesh Journal of Zoology 7: 7-14

12. Ali M, Islam MA (1981) Studies on the plankton of a lake in Bangladesh Agricultural University Campus. Bangladesh Journal of Fisheries 10: 82-88.

13. Begum MA, Kibria MM (2016) Restoration project of Halda: influence of qualitative evaluation research on fishermen. Unnoyan bitorko 2: 67-82.

14. Roy PG (2012) Physico-chemical assessment of surface water quality of Halda River. M.Sc. (Thesis) (Unpublished 149

15. Ahlstrom EH (1940) A revision of the Rotatoria genera Brachionus and platyias with description of one new species and two varieties. Bull Am Mus Nat Hist New York 77: 148-184. Link: http://bit.ly/2R3KFPC

16. Edmondson WT (1959) Freshwater Biology. $2^{\text {nd }}$ edition. New York, London: John Wiley and Sons, Inc. Link: http://bit.ly/2TgtRrr

17. Davis CC (1955) The Marine and Freshwater plankton. Michigan State Univ. Press. Chicago U.S.A 562. Link: http://bit.ly/305ZbKN

18. Pennak RW (1978) Freshwater invertebrates of the United States. Second edition. John Wiley and Sons, Inc., New York, U.S.A. 803. Link: http://bit.ly/2TaoWbt

19. Needham JG, Needham PR (1972) A guide to the study of Freshwater Biology. $5^{\text {th }}$ edition. Holden-day, Inc. San Francisco, Calif 108

20. Williamson CE (1991) Ecology and classification of North American freshwater invertebrates. Academic Press, San diago.

21. Brooks JL (1959) Cladocera. 587-656. In: W.T. Edmondson (ed.) Freshwater Biology, 2nd Ed., Wiley, New York 1248

22. Wilson MS (1959) Freshwater Biology. John Willey and Sons, New York.

Citation: Mojumder IA, Kibria MM, Bhuyan MS (2020) A baseline taxonomic study of zooplankton in the lower Halda River, Bangladesh. Glob J Zool 5(1): 001-008. DOI: https://dx.doi.org/10.17352/gjz.000013 
23. Wilson MS, Yeatman HC (1959) Freshwater Biology. John Willey and Sons, new York 851-861.

24. Smith K, Fernando CH (1978) A guide to the freshwater calanoid and Cyclopoid copepod Crustacea of Ontario. University of Waterloo, Department of Biology Ser. No.18.

25. Battish SK (1992) Freshwater zooplankton of India. Oxford and IBH publishing Co. Ltd. New Delhi. Link: http://bit.ly/2Tcofhl

26. Bhouyain AM, Asmat GS (1992) Freshwater Zooplankton from Bangladesh Dhaka. Ghazi Publishers 32-151.

27. Macan TT (1975) Freshwater ecology. London group limited, London 343

28. Mellanby H (1963) Animal life in freshwater. Cox and Wyman Ltd. London 261 Link: http://bit.ly/37YAUZX

29. Delorme LD (1967) Field key and methods of collecting freshwater Ostracods in Canada. Can J Zool 45: 1275-1281. Link: http://bit.ly/36JJPhu

30. Wickstead JH (1965) An Introduction to the study of Tropical Plankton. Hutchinson and Co. Ltd., London 160. Link: http://bit.ly/35GoXXc

31. Mizuno T (1976) Illustrations of the freshwater plankton of Japan. Hokusha Publishing Co. Ltd. Osaka, Japan 351.

32. Nayar CKG, Nair KKN (1969) A collection of brachionid rotifers from Kerala Proc Indian Acad Sci 69: 223-233. Link: http://bit.ly/35EBJ8z

33. Balcer MD, Korda NL Dodson SI (1984) Zooplankton of the Great Lakes: A guide to the identification and ecology of the common crustacean species. The University of Wisconsin Press. Madison, Wisconsin. Link: http://bit.ly/2ROKp3W

34. Victor R, Fernando $\mathrm{CH}$ (1979) The freshwater Ostracoda (Crustacea: Ostracoda) of India. Records of the Zooplankton Survey of India 74: 147-242.

35. Ahmed S (1984) Zooplankton communities of the estuarine rea of Satkhira with special reference to Ichthyoplankton. M. Sc. Thesis (Unpublished) Institute of Marine Sciences, University of Chittagong. Bangladesh 117.

36. Elias SM (1983) Zooplankton of the Mathamuhuri estuary with special reference to shrimp and finfish larvae. M. Sc. Thesis (unpublished) Institute of Marine Sciences, University of Chittagong 172.

37. Zafar M (1986) Study on Zooplankton of Satkhira in the vicinity of Aquaculture Farms with special reference to Penaeid post larvae. M.Sc. Thesis. IMS. Univ Ctg 238.

38. Mohi SA (1977) Distribution of Ichthyoplankton in the Karnafully River estuary in relation to salinity. MSc. Thesis IMS. CU 120

39. Dumont HJ (1983) Biogeography of rotifers. Hydrobiologia 104: 19-30. Link: http://bit.ly/36GofdO
40. Martin TJ, Cyrus DP (1994) Zooplankton in the open water of Lake Cubhu, a freshwater coastal lake in Zululand, South Africa. Water. South. Afri 20: 107 112

41. Akin-Oriola GA (2003) Zooplankton association and environmental factors in Ogupa and Ona rivers, Nigeria. Revi de Biol Trop 51: 391-398. Link: http://bit.ly/2seQHEE

42. Jeje $\mathrm{CY}$, Fernando $\mathrm{CH}$ (1992) Zooplankton associations in the middle Niger-Sokoto Basin (Nigeria: West Africa). Hydrobi 77: 237-253. Link: http://bit.ly/39ZMbuS

43. Rocha O, Matsumura-Tundisi T, Espíndola ELG, Roche KF, Rietzler AC (1999) Ecological theory applied to reservoir zooplankton, 457-476. In: J. G. Tundisi, \& M. Straškraba (eds.), Theoretical reservoir ecology and its applications. Internat Inst Ecol/Backhuys Publishers São Carlos. Link: http://bit.ly/2saHFZb

44. Lampert W (1997) Zooplankton research: the contribution of limnology to general ecological paradigms. Aquat Ecol 31: 19-27. Link: http://bit.ly/35B18A5

45. Carpenter SR (1988) Transmission of Variance through Lake Food Webs Complex interactions in lake communities. Springer-verlag, Berlin 199-135. Link: http://bit.ly/2QENxmX

46. Rosemond AD, Mulholland P, Elwood JW (1963) Top-down and bottom-up control of stream periphyton: effects of nutrients and herbivores. Ecol 74 $1264-1280$

47. Sharma PC, Pant MC (1985) Species composition of zooplankton in two Kumaun Himalayan lakes (UP, India). Arch Hydrobiol 102: 387-403.

48. Goldman CR, Home AJ (1983) Limnology. McGraw Hill Book Co., New York 464. Link: http://bit.ly/2QDt4ig

49. Arcifa MS, Castilho MSM, Carmouze JP (1994) Composition et evolution du zooplankton dans une lagune tropicale (Bresil) au cours dune periode marquee par une mortalite de poissons. Rev Hdrobiol Trop 27: 251-263. Link: http://bit.ly/2FEXwCg

50. Das NG, Bhuiyan AL (1981) Cladocera of Dacca city. Chittagong Univ Stud Part 2. $5: 77-86$.

51. Sharif ASM, Islam MS, Bhuyan MS (2017) Spatio-temporal occurrence and distribution of copepod in the Karnaphuli river estuary, Bangladesh. J Biodivers Environ Sci 10: 271-282. Link: http://bit.ly/35GXowG

52. Shil J, Ghosh AK, Rahman SB (2013) Abundance and diversity of Zooplankton in semi intensive prawn (Macrobrachium rosenbergii) farm. Springer Plus 2 183. Link: http://bit.ly/2QGLJcY

53. Ward HB, Whiplle GC (1966) Freshwater Biology. John Wiley and Sons Inc USA 1248.

Copyright: @ 2020 Mojumder IA, et al. This is an open-access article distributed under the terms of the Creative Commons Attribution License, which permits unrestricted use, distribution, and reproduction in any medium, provided the original author and source are credited.

Citation: Mojumder IA, Kibria MM, Bhuyan MS (2020) A baseline taxonomic study of zooplankton in the lower Halda River, Bangladesh. Glob J Zool 5(1): 001-008. DOI: https://dx.doi.org/10.17352/gjz.000013 